Afda Liza Fitri, Lince Magriastil Partisipasi Masyarakat dalam Musyawarah Perencanaan Pembangunan (Musrenbang) di Nagari Sungai Nanam Kabupaten Solok

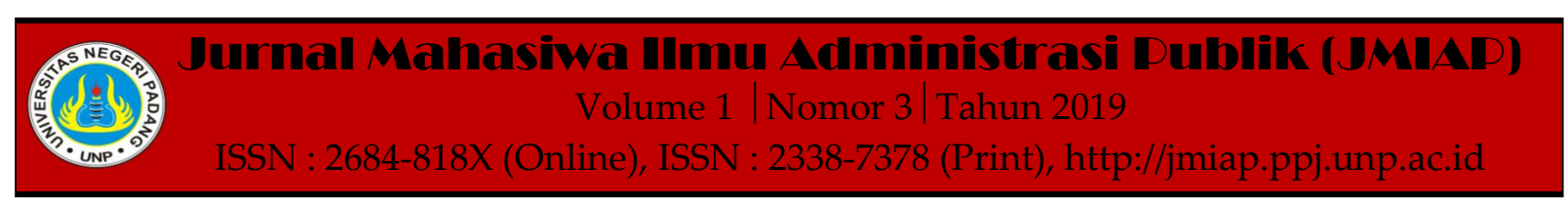

\title{
PARTISIPASI MASYARAKAT DALAM MUSYAWARAH PERENCANAAN PEMBANGUNAN (MUSRENBANG) DI NAGARI SUNGAI NANAM KABUPATEN SOLOK
}

\author{
Afda Liza Fitri ${ }^{1(a)}$, Lince Magriasti ${ }^{2(b)}$ \\ ${ }^{1}$ Jurusan Ilmu Administrasi Negara, Universitas Negeri Padang \\ ${ }^{2}$ Jurusan Ilmu Administrasi Negara, Universitas Negeri Padang \\ a)afdalizafitri@gmail.com, ${ }^{b}$ lincemagriasti@yahoo.com
}

\begin{abstract}
Development Planning Consultation (Musrenbang) is communication forum for stakeholders and people around the villageto discuss community based development. Stakeholders that should join the Musrenbang are everyone that representing all field of community life. However, in implementation at Sungai Nanam not all the stakeholders join that forum. Methods that used in this research is qualitative descriptive with interview the informant to get informations and use triangulation to analyze. From the research we knows that social participation on development palnning consultation (Musrenbang) in Sungai Nanam still on medium level. That cause by people around the village are knowledgeless about Musrenbang,they also get less information about the date of Musrenbang, their job and gender.

Keywords : Participation, Community, Musrenbang, Development

Corresponding author. Email.afdalizafitri@gmail.com, lincemagriasti@yahoo.com

How to cite this article. Fitri. A. Liza \& Magriasti. L. (2019). Partisipasi Masyarakat dalam Musyawarah Perencanaan Pembangunan (Musrenbang) di Nagari Sungai Nanam Kabupaten Solok. Jurnal Mahasiwa Ilmu Administrasi Publik (JMIAP) Jurusan Ilmu Administrasi Negara Fakultas Ilmu Sosial Universitas Negeri Padang, Volume 1 (3), Hal. 109-120.

http://jmiap.ppj.unp.ac.id

ISSN : 2684-818X (Online), ISSN : 2338-7378 (Print)

Copyright $\bigcirc 2019$. Published by Pusat Kajian-Pemberdayaan dan Pelayanan Masyarakat (PK-P2M) FIS UNP Padang
\end{abstract}




\section{PENDAHULUAN}

UU No. 32 tahun 2004 tentang Pemerintahan Daerah, merupakan landasan bagi pemerintah daerah untuk mengurus urusan pemerintahannya sendiri selama tidak bertentangan dengan UUD 1945, agar tercipta kesejahteraan, pemberdayaan, dan pelayanan yang lebih bermanfaat untuk masyarakat. Birokrasi pemerintah hingga saat ini masih diyakini sebagai ujung tombak pelaksana proses kebijakan atau program-program kerakyatan, terlebih dalam proses implementasi program karena secara legal formal jelas sekali bahwa konstitusi menjadi payung hukum yang sangat kuat bagi birokrasi untuk secara leluasa bekerja dan beraktifitas dalam proses kongkitisasi program-program yang ada (Adil Mubarak, 2012). Otonomi daerah juga bertujuan untuk membangun kemandirian suatu daerah.Berdasarkan undang-undang inilah, kemudian lahir pemerintahan terendah di Indonesia, yaitu Pemerintahan Desa.

Bentuk pemerintahan terendah di Sumatera Baratadalah pemerintahan nagari. Menurut pasal 1 ayat 2 Peraturan Daerah Sumatera Barat No. 7 tahun 2018 tentang Nagari, nagari adalah kesatuan masyarakat hukum adat secara geneologis dan historis, dengan batas-batas wilayah tertentu, mempunyai harta kekayaan sendiri, berhak memilih pemimpinnya secara musyarawarah juga mengatur dan mengurus kepentingan masyarakat berdasarkan filosofi dan sandi adat, Adat Basandi Syara' - Syara' Basandi Kitabullah, dan/atau berdasarkan asal usul dan adat istiadat setempat dalam wilayah Provinsi Sumatera Barat.

Untuk menentukan jalan dan kebijakan dalam pembangunan, pemerintah nagari melakukannya secara musyawarah.Musyawarah mengenai pembangunan ini dikenal dengan istilah Musyawarah Perencanaan Pembangunan (Musrenbang). Musrenbang dilakukan agar pembangunan yang akan dilaksanakan tersusun dan terencana dengan matang, sehingga kemungkinan kegagalannya bisa diperkecil dan hasil yang diperoleh nantinya lebih maksimal, sehingga menghasilkan pembangunan yang memberikan manfaat lebih baik dan tepat sasaran.Musrenbang merupakan mekanisme perencanaan pembangunan di daerah yang melibatkan partisipasi dari masyarakat.

Provinsi Sumatera Barat terdiri dari 19 Kabupaten/kota, 179 Kecamatan, 803 Nagari, 231 Kelurahan, dan 126 Desa(Statistik, 2018). Kabupaten Solok merupakan salah satu kabupaten yang ada di Sumatera Barat, kabupaten ini terdiri dari 14 Kecamatan dengan 74 nagari(Statistik, 2018). Salah satu kecamatan yang ada di Kabupaten Solok adalah Kecamatan Lembah Gumanti, terdiri dari 4 Nagari, salah satunya Nagari Sungai Nanam.Sungai Nanam merupakan nagari yang paling luas wilayahnya yaitu $164,54 \mathrm{Km}^{2}$, dan yang paling banyak jumlah penduduknya dibandingkan 3 nagari lain yang ada di Kec. Lembah Gumanti yaitu sebanyak 20811 jiwa dengan kepadatan $126 / \mathrm{Km}^{2}$ (Statistik, 2018).

Di Nagari Sungai Nanam, Musrenbang nagari diadakan satu kali dalam satu tahun. Waktu pelaksanaannya antara bulan November-Februari setiap tahunnya.Pada tahun 2018 kegiatan Musrenbang di Nagari Sungai Nanam dilaksanakan minggu kedua bulan November, kegiatan ini dihadiri oleh 153 orang masyarakat dengan komposisi 77 orang laki-laki, 76 orang perempuan. Jumlah tersebut mengalami penurunan dari jumlah masyarakat yang hadir pada Musrenbang tahun 2017, yaitu sebanyak 185 orang dengan komposisi 84 orang lakilaki, 101 orang perempuan. Jumlah tersebut sangat sedikit dibandingkan dari jumlah penduduk yang ada di kenagarian tersebut yaitu sebanyak 20.811 jiwa.Dari uraian tersebut diketahui bahwa partisipasi masyarakat dalam kegiatan Musrenbang masih tergolong sedikit. 
Afda Liza Fitri, Lince Magriastil Partisipasi Masyarakat dalam Musyawarah Perencanaan Pembangunan (Musrenbang) di Nagari Sungai Nanam Kabupaten Solok

Menurut keterangan yang diperoleh saat wawancara awal dengan sekretaris Nagari Sungai Nanam, Harmisriono AD, latar belakang pekerjaan masyarakat yang sebagian besar adalah petani, menyebabkan kurangnya minat masyarakat untuk ikut berpartisipasi dalam kegiatan Musrenbang Nagari.Mereka lebih memilih untuk bekerja di ladangnya, daripada harus mengikuti kegiatan Musrenbang. Mereka menganggap kegiatan Musrenbang hanya membuangbuang waktu saja, tanpa adanya partisipasi mereka pun kegiatan tersebut akan tetap berjalan. Sementara itu, menurut hasil wawancara awal dengan salah seorang masyarakat setempat, ia mengatakan:

"saya sebagai masyarakat biasa belum pernah ikut yang namanya Musrenbang, saya tidak tau apa itu Musrenbang, baru sekali ini saya mendengar namanya, tidak ada orang dari kantor wali nagari yang menjelaskan tentang Musrenbang. Saya belum pernah mendengar pengumuman kapan akan dilaksanakan Musrenbang, biasanya jika ada pengumuman, akan di umumkan di masjid-masjid, tapi kalau Musrenbang ini tidak pernah di umumkan di Masjid"

Berdasarkan permasalahanpermasalahan tersebut, penulis tertarik untuk melakukan penelitian dan mengambil permasalahan ini untuk dijadikan sebagai skripsi yang berjudul "Partisipasi Masyarakat dalam Musyawarah Perencanaan Pembangunan (Musrenbang) di Nagari Sungai Nanam Kabupaten Solok".

\section{TINJAUAN PUSTAKA}

\section{Konsep Partisipasi Masyarakat}

(Slamet, 2006) mengatakan bahwa partisipasi anggota masyarakat merupakan keikutsertaan anggota masyarakat dalam pembangunan, mencakup kegiatan dalam perencanaan dan pelaksanaan (implementasi) rencana pembangunan yang dikerjakan masyarakat setempat. Partisipasi atau keikutsertaan masyarakat dalam kegiatan pembangunan adalah bentuk kesediaan dan kemampuan masyarakat untuk berkorban dan berperan dalam pelaksanaan kegiatan yang akan dilaksanakan.

(Mustanir, 2017) juga menjelaskan bahwa partisipasi masyarakat adalah keterlibatan atau keikutsertaan seseorang dalam proses interaksi sosial, pengidentifikasian masalah dan potensi yang ada di masyarakat dalam keadaan tertentu, baik dalam pengambilan keputusan (solusi) menangani masalah, pelaksanaan upaya mengatasi masalah, dan proses keterlibatan masyarakat di dalam mengevaluasi perubahan yang terjadi.

\section{Bentuk-bentuk Partisipasi}

(Totok \& Poerwoko, 2015) mengemukakan bentuk-bentuk partisipasi sebagai berikut:

a. Partisipiasi dalam pengambilan keputusan

b. Partisipasi dalam pelaksanaan kegiatan

c. Partisipasi dalam pemantauan dan evaluasi pembangunan

d. Partisipasi dalam pemanfaatan hasil-hasil pembangunan

Dusseldorp (Slamet, 2006) membagi partisipasi menjadi beberapa bentuk golongan, diantaranya:

a. Berdasarkan derajat kesukarelaan:

1) Partisipasi bebas, apabila seseorang terlibat secara sukarela dalam sebuah kegiatan. Partisipasi ini terbagi dua, pertama partisipasi spontan, yaitu berdasarkan inisiatif sendiri tanpa adanya pengaruh dari luar diri orang tersebut. Kedua, partisipasi terbujuk, dimana seseorang mulai berpartisipasi setelah adanya penyuluhan atau ajakan dari orang lain. 
2) Partisipasi terpaksa, terbagi kedalam dua jenis, pertama terpaksa oleh hukum dimana seseorang terpaksa berpartisipasi karena adanya hukum yang menuntut untuk berpartisipasi. Kedua, terpaksa karena kondisi sosial ekonomi, yaitu seseorang enggan berpartisipasi tetapi karena pengaruh sosial dan kesulitan ekonomi mereka harus ikut berpartisipasi.

b. Berdasarkan cara keterlibatan:

1) Partisipasi langsung, jika seseorang melibatkan dirinya dalam sebuah kegiatan pembangunan, misalnya turut serta hadir dalam pertemuan/ rapat mengenai suatu kegiatan.

2) Partisipasi tidak langsung, jika seseorang mewakilkan dirimya untuk berpartisipasi kepada orang lain.

2. Tingkatan Partisipasi

Menurut Cohen dan Uphoff (Deviyanti, 2013), mereka membagi partisipasi masyarakat dalam 4 tingkatan, diantaranya:

a. Partisipasi dalam perencanaan;

b. Partisipasi dalam pelaksanaan;

c. Partisipasi dalam pemanfaatan hasil;

d. Partisipasi dalam evaluasi;

Wilcox (Theresia et al., 2014) mengemukakan ada 5 (lima) tingkatan partisipasi, antara lain:
a. Information
(Memberikan
Informasi)
Merupakan tingkat awal partisipasi, yaitu memberikan informasi yang diketahui untuk manfaat tertentu.
b. Consultation (Konsultasi)
Menawarkan pendapat, sebagai pendengar yang baik untuk memberikan umpan-balik, tetapi tidak terlibat dalam implementasi.

c. Deciding Together (Pengambilan Keputusan Bersama)

Memberikan dukungan terhadap ide, gagasan, pilihan-piliha, serta mengembangkan peluang yang diperlukan guna pengambilan keputusan.

d. Acting Together (Bertindak Bersama)

Tidak hanya ikut dalam pengambilan keputusan, tapi juga terlibat dalam menjalin kemitraan dalam pelaksanaan kegiatannya.
e. Supporting independent community interest (Memberi Dukungan)
Kelompok-kelompok lokal menawarkan pendanaan, nasehat, dan dukungan lain untuk mengembangkan agenda kegiatan.

3. Faktor Penghambat Partisipasi Masyarakat

Dalam (Dwiningrum, 2011),faktorfaktor yang bisa menhambat partisipasi masyarakat adalah sebagai berikut:

a. Sifat malas,apatis,masa bodoh dan tidak mau melakukan perubahan dalam anggota masyarakat.

b. Aspek tipologis

c. Aspek geografis (pulau-pulau kecil)

d. Aspek demografis (jumlah penduduk)

e. Aspek ekonomi (desa miskin/tertinggal)

Slamet (Deviyanti, 2013), mengemukakan faktor penghambat partisipasi masyarakat yang berasal dari dalam kelompok masyarakat itu sendiri. Tingkah laku individu berkaitan erat dengan ciri-ciri sosiologisnya, seperti umur, jenis kelamin, pengetahuan, pekerjaan, penghasilan. Secara teoritis terdapat hubungan antara ciri-ciri individu dengan tingkat partisipasi, seperti usia, tingkat pendidikan, jenis pekerjaan, lamanya menjadi anggota masyarakat, besarnya pendapatan, keterlibatan dalam kegiatan 
Afda Liza Fitri, Lince Magriastil Partisipasi Masyarakat dalam Musyawarah Perencanaan Pembangunan (Musrenbang) di Nagari Sungai Nanam Kabupaten Solok

pembangunan akan sangat berpengaruh pada partisipasi.

\section{Konsep Musrenbang}

Musrenbang adalah singkatan dari musyawarah perencanaan pembangunan. Musrenbang merupakan forum perencanaan yang disediakan oleh pemerintah,dalam hal ini pemerintah desa,dengan melibatkan warga masyarakat dan pemagku kepentingan lainnya.

Fikri (2015: 67-68) menjelaskan urutan proses kegiatan Musrenbang, antara lain:
a. Musrenbangdes (diadakan di tingkat Desa)
b. Musrenbangcam (diadakan di tingkat Kecamatan)
c. Musrenbangkab (diadakan di tingkat Kabupaten)\}
d. Musrenbangprov (diadakan di tingkat Provinsi)
e. Musrenbangnas (diadakan di tingkat Nasional)

Musrenbang dilakukan sebagai wujud pelaksanaan amanat Undang-Undang No. 25 Tahun 2004 tentang Sistem Perencanaan Pembangunan Nasional, teknis pelaksanaannya diatur dengan Surat Edaran Bersama (SEB) Menteri Negara Perencanaan Pembangunan Nasional, Permendagri No. 66 tentang Perencanaan Desa yang berisi petunjuk teknis pelaksanaan Musrenbang untuk menyusun RPJM Desa 5 tahunan dan RKP Desa tahunan. Selain itu, amanat UndangUndang No. 32 Tahun 2004 tentang Pemerintah Daerah; Peraturan Pemerintah No. 72 Tahun 2005 tentang Pemerintahan Desa; Keputusan Mendagri Nomor: 050187/Kep/Bangda/2007 tentang Pedoman Penilaian dan Evaluasi Pelaksanaan Penyelenggaraan Musrenbang; Peraturan Pemerintah No.8 Tahun 2008 tentang Tahapan Tata Cara Penyusunan, Pengendalian dan Evaluasi Pelaksanaan Rencana Pembanguan Daerah; Peraturan Daerah Provinsi Sumatera Barat No. 7 Tahun 2008 tentang Rencana Pembangunan Jangka Panjang Daerah
Provinsi Sumatera Barat Tahun 2005-2025; dan Peraturan Daerah Kabupaten Solok Nomor 7 Tahun 2015 tentang Sistem Perencanaan Pembangunan dan Penganggaran Daerah.

Tujuan Musrenbang Nagari. (Djohani, 2008) mengatakan,adapun tujuan diadakannya Musrenbang Nagari adalah sebagai berikut:

a. Menyepakati prioritas kebutuhan/masalah dan kegiatan nagari yang akan menjadi bahan penyusunan Rencana Kerja Pembangunan Nagari,dengan pembagian antara lain:

b. Prioritas kegiatan nagari yang akan dilaksanakan oleh nagari sendiri dan dibiayai melalui dana swadaya nagari/masyarakat.

c. Prioritas kegiatan nagari yang akan dilaksanakan oleh nagari sendiri dan dibiayai melalui Alokasi Dana Nagari (ADN) yang berasal dari APBD kabupaten/kota atau sumber lainnya.

d. Prioritas masalah daerah yang ada di nagari yang akan diusulkan melalui Musrenbang kecamatan untuk menjadi kegiatan pemerintah daerah dan dibiayai melalui APBD kabupaten/kota atau APBD provinsi.

e. Menyepakati tim delegasi nagari yang akan memaparkan persoalan daerah yang ada di nagarimya kepada forum Musrenbang Kecamatan untuk penyusunan program pemerintah daerah/ SKPD tahun berikutnya.

Peserta Musrenbang Nagari. Musrenbang akan lebih ideal jika berbagai komponen masyarakat baik individu maupun kelompok ikut serta dalam kegiatan tersebut. Adapun komposisi peserta Musrenbang yaitu:
a. Keterwakilan wilayah (dusun/kampung/RT/RW) 
b. Keterwakilan berbagai sektor (ekonomi/pertanian/kesehatan/lin gkungan/pendidikan)

c. Keterwakilan kelompok usia (generasi muda dan tua)

d. Keterwakilan kelompok sosial dan perempuan (tokoh masyarakat,tokoh adat,tokoh agama,bapak-bapak,ibuibu,kelompok marjinal)

e. Keterwakilan 3 unsur tata pemerintahan (pemerintah nagari,masyarakat umum,dan kalangan swasta)

f. Keterwakilan berbagai organisasi yang menajdi pemangku kepentingan dalam pembangunan nagari.

\section{METODE PENELITIAN}

Dalam penelitian ini metode yang digunakan yaitu metode kulaitatif deskriptif.Penelitian ini berlokasi di Nagari Sungai Nanam Kabupaten Solok.Fokus dalam penelitian ini adalah terkait partisipasi masyarakat dalam Musrenbang serta faktor yang menghambat partisipasi masyarakat dalam Musrenbang di Nagari Sungai Nanam Kabupaten Solok.Dalam penelitian ini informan ditentukan menggunakan teknik purposive sampling.Jenis data dalam penlitian ini adalah data primer dan data sekuder yang diperoleh dengan teknik wawanacara dan studi dokumentasi.Alat yang digunakan untuk mengumpulkan data saat penelitian adalah pedoman wawancara.Data tersebut diuji keabsahannya dengan menggunakan teknik triangulasi metode. Kemudian data dianalisis dengan cara melakukan reduksi data, setelah itu data disajikan kemudian disimpulkan.

\section{HASIL DAN PEMBAHASAN}

Untuk mengetahui partisipasi masyarakat dalam kegiatan Musrenbang di Nagari Sungai Nanam Kabupaten Solok, peneliti memakai teori dari Dusseldorp mengenai derajat partisipasi masyarakat yang diukur berdasarkan derajat kesukarelaan dan cara keterlibatan. Sedangkan untuk mengetahui faktor apa saja yang menghambat partisipasi masyarakat dalam kegiatan Musrenbang di Nagari Sungai Nanam Kabupaten Solok peneliti memakai teori yang dikemukakan oleh slamet, yang mengatakan bahwa faktor-faktor yang mempengaruhi partisipasi masyarakat diantaranya usia, jenis kelamin, pekerjaan, tingkat pendidikan dan tingkat penghasilan

\section{Tingkat Partisipasi Masyarakat dalam Musyawarah Perencanaan Pembangunan (Musrenbang) di Nagari Sungai Nanam Kabupaten Solok.}

Diukur berdasarkan derajat
kesukarelaan
Dalam Musrenbang di Nagari Sungai Nanam Kabupaten Solok, partisipasi masyarakat tergolong pada tingkat partisipasi bebas terbujuk, hal ini dikarenakan masyarakat yang hadir dalam Musrenbang adalah masyarakat yang di undang oleh pemerintah nagari. Sesuai dengan hasil wawancara peneliti dengan salah satu peserta Musrenbang, Dodi, yang mengatakan bahwa ia menghadiri kegiatan Musrenbang sebagai delegasi ketua komite SD, karena di undang oleh pemerintah nagari.

Hal yang sama juga disampaikan oleh Suardi, salah seorang kepala Jorong sekaligus sekretaris Kerapatan Adat Nagari (KAN) Sungai Nanam Kabupaten Solok menyampaikan tentang alasannya mengikuti kegiatan Musrenbang nagari (wawancara 9 Oktober 2019), ia mengaku hadir dalam kegiatan Musrenbang karena seluruh jajaran KAN Sungai Nanam dan seluruh kepala jorong di undang oleh pihak pemerintah nagari.

Sementara itu, Masyarakat yang tidak mendapatkan undangan biasanya jarang datang untuk mengikuti kegiatan Musrenbang, hal tersebut disebabkan oleh entah itu karena merasa segan untuk hadir karena tidak adanya undangan atau 
memang enggan untuk hadir dalam kegiatan Musrenbang, hal ini seperti yang dijelaskan oleh Parlis, selaku ketua Kerapatan Adat Nagari (KAN) Sungai Nanam saat wawancara 9 Oktober 2019, yang mengatakan:

"Dalam kegiatan Musrenbang
memang tidak semua masyarakat di
undang, yang di undang hanya orang-
orang tertentu saja, karena kalaupun
diundang semua, pemerintah juga
tidak sanggup menampungnya karena
keterbatasan lokasi. Jadi masyarakat
yang tidak mendapat undangan
biasanya tidak ada yang hadir untuk
mengikuti Musrenbang, mungkin
karena merasa segan".

Selain datang karena mendapat undangan dari pihak pemerintah nagari, peserta yang hadir dalam kegiatan Musrenbang nagari juga ada yang datang karena adanya ajakan dari orang lain yang telah mendapatkan undangan dari pihak nagari. Seperti yang disampaikan Ridal Putra saat wawancara 9 Oktober 2019, ia mengatakan, "Saya mengikuti kegiatan Musrenbang itu karena diajak oleh kepala Jorong sehari sebelum kegiatan Musrenbang tersebut dilakukan, sebelumnya saya tidak tahu apa itu Musrenbang, tetapi karena diajak akhirnya saya pergi untuk menghadiri kegiatan Musrenbang nagari tersebut". Berdasarkan keterangan narasumber, diketahui bahwa Ridal Putra menghadiri kegiatan Musrenbang Nagari Sungai Nanam bukan karena mendapat undangan dari pihak pemerintah Nagari Sungai Nanam, tetapi dia menghadiri kegiatan tersebut karena mendapat ajakan dari kepala jorong tempat dia berada.

Berdasarkan hasil penelitian di lapangan, masyarakat ikut berpartisipasi dalam kegiatan Musrenbang tidak ada yang melakukannya karena terpaksa, baik itu terpaksa oleh orang lain ataupun terpaksa oleh hukum maupun keadaan. Hal ini ternyata tidak sesuai dengan pendapat yang dikemukakan oleh Dusseldorp yang mengatakan bahwa berdasarkan derajat kesukarelaan, partisipasi masyarakat terbagi atas pasrtisipasi bebas dan partisipasi terpaksa.Di nagari Sungai Nanam Kabupaten Solok, masyarakat berpartisipasi dalam kegiatan Musrenbang secara bebas, walaupun terbujuk setelah mendapat undangan atau diajak oleh orang lain, tetapi tidak ada unsur keterpaksaan bagi masyarakat yang mengikuti kegiatan Musrenbang nagari tersebut.

b) Berdasarkan cara keterlibatannya

Dilihat dari cara keterlibatannya, partisipasi masyarakat Nagari Sungai Nanam terdiri dari partisipasi langsung dan partisipasi tidak langsung. Partisipasi langsung adalah ketika masyarakat terlibat langsung dalam kegiatan Musrenbang nagari, ikut menyampaikan pendapat secara langsung dalam Musrenbang. Seperti yang disampaikan oleh Fauzan Zul Asri, selaku perwakilan pemuda saat wawancara pada 9 Oktober 2019 ia mengatakan, " Saat Musrenbang saya ikut menyampaikan usulan secara langsung didalam forum".

Dari penjelasannya dapat diketahui bahwa Fauzan berpartisipasi secara langsung dalam kegiatan Musrenbang, yaitu dengan menyampaikan usulan secara langsung didalam forum kegiatan Musrenbang. Hal yang sama juga dikatakan oleh Noferma, sekretaris BPN sekaligus anggota Bundo Kanduang Nagari Sungai Nanam, dalam wawancara 9 Oktober 2019, ia menyebutkan, " Dalam Musrenbang etek juga ikut menyampaikan pendapat, etek menyampaikannya di dalam forum, etek menyampaikan usulan sebagai perwakilan dari Bundo Kanduang”.

Dari penjelasan tersebut dapat di pahami bahwa ia terlibat partisipasi langsung dalam kegiatan Musrenbang nagari. Selain partisipasi langsung, masyarakat Nagari Sungai Nanam juga berpartisipasi secara tidak langsung dalam Musrenbang nagari, seperi yang disampaikan Ridal Putra, dalam wawancara 
Afda Liza Fitri, Lince Magriastil Partisipasi Masyarakat dalam Musyawarah Perencanaan Pembangunan (Musrenbang) di Nagari Sungai Nanam Kabupaten Solok

9 Oktober 2019, “ Dalam Musrenbang saya tidak menyampaikan pendapat secara langsung, akan tetapi saya ikut menyampaikan pendapat secara tertulis". Dari penjelasan tersebut, dapat diketahui bahwa partisipasi yang dilakukannya adalah partisipasi tidak langsung. Hal serupa juga dikatakan oleh Firmansyah Arif, kepala jorong Taratak Pauah, saat wawancara 10 Oktober 2019 ia menjelaskan, " Masyarakat tidak hanya menyampaikan usulannya secara langsung, ada juga yang secara tidak langsung, seperti menitipkan sarannya kepada kepala jorong saat dilakukan rembug jorong, agar disampaikan dalam forum Musrenbang".

Berdasarkan penjelasan Bapak Firman tersebut, dapat disimpulkan bahwa keterlibatan masyarakat dalam Musrenbang di Nagari Sungai Nanam tidak hanya secara langsung tetapi juga secara tidak langsung, yaitu dengan menitipkan usulan yng ingin disampaikannya kepada kepala jorong untuk disampaikan dalam forum Musrenbang.

Hasil penelitian menunjukkan bahwa partisipasi masyarkat dalam Musrenbang Nagari Sungai Nanam Kabupaten Solok terdiri dari partisipasi langsung dan tidak langsung.Partisipiasi langsung masyarakat dapat terlihat dari masyarakat yang menyampaikan usulannya secara langsung didalam forum kegiatan Musrenbang nagari. Sedangkan partisipasi tidak langsung masyarakat dapat terlihat dari masyarakat yang tidak hadir dalam Musrenbang nagari, akan tetapi mengikuti kegiatan rembug jorong, kemudian menitipkan usulannya kepada kepala jorong. Selain itu partisipasi tidak langsung masyarakat juga dapat dilihat dari masyarakat yang menyampaikan usulannya tidak secara langsung didalam forum, tetapi secara tertulis didalam kertas.

Bentuk partisipasi masyarakat dalam kegiatan Musrenbang di Nagari Sungai Nanam yang ditemui di lapangan tersebut sesuai dengan teori yang dikemukakan
Dusseldorp, yang mengatakan bahwa partisipasi masyarkat jika dilihat dari cara keterlibatannya dapat berupa partisipasi langsung dan tidak langsung.

\section{Faktor Penghambat Partisipasi Masyarakat dalam Musyawarah Perencanaan Pembangunan (Musrenbang) di Nagari Sungai Nanam Kabupaten Solok}

Dalam Musrenbang di Nagari Sungai Nanam Kabupaten Solok, tidak semua masyarakat hadir untuk mengikuti kegiatan terebut. Masyarakat yang hadir rata-rata berusia 24 - 60 tahun, hal ini seperti keterangan Damhuri, ketua LPMN Sungai Nanam saat wawancara 12 Oktober 2019 ia menjelaskan, " Kebanyakan yang hadir saat Musrenbang masyarakat yang berumur antara 35 - 45 tahun, ada juga anak-anak muda yang umurnya sekitar 24 tahun tapi paling banyak hanya 4 orang. Tapi yang menyampaikan pendapat tidak menentu umurnya, semuanya sama rata saja." Berdasarkan penjelasan narasumber tersebut, dapat diketahui bahwa masyarakat yang hadir kebanyakan adalah masyarakat yang memiliki renatng usia 35-45 tahun. Namun dalam menyampaikan pendapat tidak ada usia masyarakat yang dominan.

Dari seluruh masyarakat yang hadir, juga tidak seluruhnya yang ikut berpartisipasi aktif menyampaikan usulannya dalam forum Musrenbang tersebut. Hal ini seperti yang diungkapkan saat wawancara dengan Noferma, 9 Oktober 2019, yang mengtakan, "Saat Musrenbang yang lebih sering menyampaikan pendapat atau usulan itu yang laki-laki, karena dia lebih berani. Kalau yang perempuan kan masih ada rasa malu-malu untuk menyampaikan pendapat, sedangkan yang laki-laki tidak”.

Dari keterangan tersebut, dapat diketahui yang lebih sering menyampaikan pendapat adalah peserta laki-laki. Hal yang sama juga disampaikan Atma Winarni saat wawancara pada 9 Oktober 2019, ia menjelaskan: 
"Yang ibuk lihat saat Musrenbang, yang lebih sering menyampaikan pendapat itu adalah peserta laki-laki, berhubung pesertanya yang banyak hadir juga yang laki-laki, sementara yang perempuan lebih sedikit, mungkin karena kalau yang perempuan dikampung kita kan banyak yang dikerjakan, mengurus anak, mengurus rumah, jadi untuk mengikuti Musrenbang mereka agak kurang berminat untuk mengikutinya "

Dari penjelasan Ibu Winarni tersebut, diketahui bahwa faktor gender/ jenis kelamin mempengaruhi partisipasi masyarakat dalam Musrenbang di Nagari Sungai Nanam. Hal tersebut di benarkn oleh sekretaris Nagari Sungai Nanam, Harmisriono AD, beliau mengatakan,

“ Saat Musrenbang di nagari kita, pesertanya yang lebih banyak itu yang laki-laki, maklum di nagari kita ini kaum ibu-ibu banyak kerjaannya, misalnya yang punya anak kecil, kan tidak mungkin di bawa anaknya untuk mengikuti Musrenbang"

Penjelasan tersebut juga sesuai dengan daftar hadir Musrenbang (dapat dilihat pada lampiran), disana terlihat bahwa peserta laki-laki lebih banyak dari peserta perempuan.

Adrizal, S.Hum salah seorang perwakilan kelompok tani Sungai Nanam menjelaskan bahwa yang menyebabkan kurangnya partisipasi masyarakat dalam musrenbang adalah kurangnya pengetahuan masyarakat tentang pentingnya berpartisipasi dalam Musrenbang, ia menyampaikan saat wawancara pada 12 Oktober 2019 bahwa:

"salah satu faktor yang menyebabkan tidak berpartisipasinya masyarakat dalam Musrenbang di nagari kita adalah karena masyarakat kita banyak yang tidak tahu manfaat Musrenbang ini, sehingga masyarakat lebih mementingkan pekerjaannya diladang daripada harus berpartisipasi dalam Musrenbang. Padahal Musrenbang ini sangat besar manfaatnya, disinilah awal mulanya pembangunan di sebuah nagari”.

Berdasarkan keterangan tersebut, dapat dipahami bahwa faktor yang menghambat partisipasi masyarakat dalam Musrenbang adalah ketidaktahuan masyarakat tentang manfaat Musrenbang. Hal tersebut juga dibenarkan oleh Adrizal S.Sos, selaku Plt. Wali Nagari Sungai Nanam pada wawancara 12 Oktober 2019, beliau mengatakan:

" Masyarakat kita masih banyak yang tidak tahu betapa pentingnya Musrenbang nagari ini. Kemudian latar belakang pekerjaan masyarakat kita yang rata-rata adalah petani, juga menjadi faktor kurangnya partisipasi masyarakat,mereka mungkin merasa rugi jika harus meninggalkan pekerjan diladang hanya untuk mengikuti Musrenbang ".

Dari penjelasan tersebut, dapat diketahui bahwa latar belakang pekerjaan masyarakat juga menjadi faktor penghambat partisipasi masyarakat dalam Musrenbang di Nagari Sungai Nanam.

Faktor-faktor yang ditemui dilapangan tersebut tidak sesuai dengan yang dikemukakan oleh Slamet, yang mengatakan bahwa faktor-faktor yang menghambat partisipasi masyarakat adalah usia, jenis kelamin, tingkat pendidikan, tingkat penghasilan dan mata pencaharian. Dari 5 faktor yang dikemukakan oleh Slamet tersebut hanya dua faktor yang ditemui dengan realita di lapangan, yaitu faktor jenis kelamin dan pekerjaan.

\section{Upaya Pemerintah Nagari untuk Meningkatkan Partisipasi Masyarakat dalam Musrenbang}

Dari hasil wawancara dengan berbagai narasumber dari berbagai kalangan, diketahui bahwa Musrenbang di Nagari Sungai Nanam masih mengalami kendala 
berupa kurangnya partisipasi masyarakat dalam Musrenbang tersebut. Untuk meningkatkan hal tersebut, sepenuhnya merupakan tanggung jawab dari pihak pemerintah nagari, upaya yang dapat dilakukan pemerintah diantaranya seperti yang disampaikan Delfiza dalam wawancara 12 Oktober 2019, ia mengusulkan, "untuk meningkatkan partisipasi masyarakat, pemerintah nagari sebaiknya mensosialisasikan tentang pentingnya Musrenbang nagari ini kepada masyarakat, agar masyarakat awam tahu benar manfaat dari Musrenbang nagari "

Misardi S.Sos selaku ketua PPN Sungai Nanam, juga mengatkan dalam wawancara 12 Oktober 2019:

"agar partisipasi masyarakat dalam Musrenbang nagari meningkat, pemerintah sebaiknya banyak mengabulkan usulan-usulan yang disampaikan oleh masyarakat saat Musrenbang, sehingga itu akan menjadi motivasi bagi masyarakat untuk terus mengikuti MusrenbangMusrenbang di tahun berikutnya ".

Dari informasi tersebut, upaya yang harus dilakukan pemerintah agar partisipasi masyarakat dalam kegiatan Musrenbang nagari meningkat adalah dengan mengabulkan usulan-usulan yang disampaikan oleh masyarakat saat kegiatan Musrenbang, sehingga akan memotivasi masyarakat untuk menghadiri kegiatan Musrenbang tahun selanjutnya.

Ada beberapa upaya yang dilakukan oleh pihak pemerintah nagari untuk meningkatkan partisipasi masyarakat dalam kegiatan Musrenbang nagari, Pertama, dengan menerima aspirasi yang diusulkan oleh masyarakat dalam forum kegiatan Musrenbang, dan berupaya mewujudkannya dalam bentuk pembangunan nagari yang lebih baik. Jika masyarakat melihat tindakan nayata bahwa aspirasinya diterima dan diwujudkan, maka akan menumbuhkan minat masyarakat untuk lebih berpartisipasi dalam kegiatan Musrenbang Nagari.

Kedua, dengan menyelenggarakan kegiatan rembug jorong sebelum melakukan kegiatan Musrenbang. Dengan melakukan kegiatan rembug jorong, masyarakat akan bersemangat untuk mencari apa kebutuhan yang akan disampaikan saat forum Musrenbang, sehingga akan menimbulakn keinginan masyarakat mengikuti kagiatan Musrenbang.

Selain upaya yang telah disampaikan tadi, menurut peneliti ada beberapa upaya yang harusnya dilakukan oleh pemerintah nagari untuk meningkatkan partisipasi masyarakat dalam Musrenbang.Pertama, pihak pemerintah nagari sebaiknya memberikan sosialisasi kepada masyarakat tentang pentingnya partisipasi masyarakat dalam Musrenbang, serta kerugiankerugian yang didapatkan akibat tidak berpartisipasi dalam kegiatan Musrenbang. Sehingga masyarakat akan termotivasi mengikuti kegiatan Musrenbang.

Upaya selanjutnya yang harus dilakukan oleh pemerintah untuk meningkatkan partisipasi masyarakat dalam kegiatan Musrenbang nagari adalah memastikan bahwa seluruh lapisan masyarakat mendapatkan informasi mengenai jadwal pelaksnaan kegiatan Musrenbang nagari. Agar masyarakat dapat mempersiapkan dirinya untuk menghadiri kegiatan Musrenbang nagari, karena banyak masyarakat yang mengaku bahwa tidak mengetahui tentang waktu pelaksanaan kegiatan Musrenbang nagari tersebut.

\section{PENUTUP}

Berdasarkan hasil penelitian dan pembahasan yang telah peneliti lakukan, dapat disimpulkan beberapa hal, yaitu:

a) Tingkat partisipasi masyarakat dalam Musrenbang di Nagari Sungai Nanam Kabupaten Solok masih tergolong sedang, hal ini 
karena untuk berpartisipasi dalam kegiatan Musrenbang, masyarakat Nagari Sungai Nanam tidak ada yang melakukannya karena adanya inisiatif atau kesadarannya sendiri, akan tetapi karena ada undangan atau ajakan dari orang lain terlebih dahulu.

b) Terdapat empat faktor yang menghambat partisipasi masyarakat dalam Musrenbang di Nagari Sungai Nanam Kabupaten Solok, yaitu kurangnya informasi mengenai waktu pelaksanaan Musrenbang, kurangnya pengetahuan masyarakat akan pentingnya Musrenbang, faktor pekerjaan, dan jenis kelamin.

c) Adapun upaya yang dilakukan pihak pemerintah Nagari Sungai Nanam untuk meningkatkan partisipasi masyarakat dalam Musrenbang adalah dengan menerima dan mewujudkan aspirasi yang diusulkan oleh masyarakat dalam Musrenbang, sehingga dengan begitu masyarakat akan merasa didengar dan diperhatikan, kemudian akan memancing kesadaran dan memotivasi masyarakat untuk berpartisipasi dalam kegiatan Musrenbang selanjutnya.

Dari hasil penelitian tersebut, ada beberapa saran yang ingin peneliti sampaikan untuk meningkatkan partisipasi masyarakat dalam Musrenbang, yaitu:

a) Pemerintah nagari sebaiknya memberikan sosialisasi kepada masyarakat tentang betapa pentingnya partisipasi masyarakat dalam Musrenbang.

b) Agar seluruh lapisan masyarakat mengetahui mengenai informasi pelaksanaan Musrenbang, sebaiknya diumumkan melalui pengeras suara dengan menggunakan mobil kemudian berkeliling dii seluruh daerah yang ada di Nagari Sungai Nanam. Hal ini dirasa sangat efektif, karena pasti seluruh masyaralat akan mendengarnya, sehingga tidak ada lagi masyarakat yang akan ketinggalan informasi.

\section{DAFTAR KEPUSTAKAAN}

Adil Mubarak. (2012). Model Impelementasi Program dalam Upaya Pencapaian Sasaran MDGs 2015 ( Strategi Bagi Birokrasi Sebagai Ujung Tombak Implementasi 8 sasaran MDGs). Repository.Ut.Ac.Id. http://repository.ut.ac.id/2402/1/fisip2 01206.pdf

Deviyanti, D. (2013). Studi tentang Partisipasi Masyarakat dalam Pembangunan di Kelurahan Karang Jati Kecamatan Balikpapan Tengah. Jurnal Administrasi Negara, 1(2), 380394.

Djohani, R. (2008). Panduan penyelenggaraan musyawarah perencanaan pembangunan desa. Bandung: The Asia Foundation Dan FPPM.

Dwiningrum, S. I. A. (2011). Desentralisasi dan partisipasi masyarakat dalam pendidikan. Pustaka Pelajar.

Mustanir, A. (2017). Partisipasi Masyarakat Dalam Musyawarah Rencana Pembangunan Di Kelurahan Kanyuara Kecamatan Watang Sidenreng Kabupaten Sidenreng Rappang. JPP (Jurnal Politik Profetik), 5(2), 247261.

Slamet, Y. (2006). Pembangunan masyarakat berwawasan partisipasi. Sebelas Maret University Press.

Statistik, B. pusat. (2018). Provinsi Sumatera Barat Dalam Angka 2018. 
Afda Liza Fitri, Lince Magriastil Partisipasi Masyarakat dalam Musyawarah Perencanaan Pembangunan (Musrenbang) di Nagari Sungai Nanam Kabupaten Solok

Theresia, A., Andini, K. S., Nugraha, P. G. P., \& Mardikanto, T. (2014).

Totok, M., \& Poerwoko, S. (2015). Pembangunan berbasis masyarakat: Pemberdayaan Masyarakat Dalam Acuan bagi praktisi, akademisi, dan Perspektif Kebijakan Publik. Alfabeta. pemerhati pengembangan masyarakat. Penerbit Alfabeta. 